\title{
Critical Aspects in Design and Construction of Open Type Shallow Highway Girders Across Railways.
}

\author{
Geetha M. P., Girija K.
}

\begin{abstract}
A highway bridge across railways in-lieu of the level crossing will surely be smoothening the road traffic and the rail traffic. Hence, it is essential to bridge across the railways at all the level crossing locations in a developing country. Due to the introduction of a bridge across a busy railway track, the necessity to negotiate the level difference happens. This level difference is more with the usage of the conventional type of girders. By this, the delay of the project due to land acquisition is considerable. The most suitable superstructure for such highway bridge is the deck with shallow open type pre-stressed girders. When multiple shallow, open-type girders are placed adjacently and integrated with a deck slab above these, the load distribution and sharing between girders are to be refined based on experimental studies and authors discussed the same within this paper. An experimental study on two Double-T cross-section pre-stressed model girders and deck assembly revealed the structural behaviour between girders. The results from the two-point load testing helped in developing various design methodologies in this study. An escalation of $17 \%$ in the design forces need to be considered on the results obtaining from the grillage analysis, to cater the unbalanced forces on the individual web of the open-type girder, during the eccentric loading condition. The Authors elaborated the design of shear friction reinforcement. The self-managing capacity of the spreading tendency of the webs of this type of girders is due to the counteracting of radial pressure generated from the pre-stressing force. The critical aspects of construction also dealt with in this paper without which the usage of open-type girders with ends closed cannot be encouraged. The authors developed conceptual designs for the removable internal shutter, launching scheme and demolishing of the bridge superstructure, in this study. The dismantling of the bridge is a rare requirement arises only when the number of track increases. The reuse of girder-deck assembly is also found possible and suggested in this paper.
\end{abstract}

Key words: Shallow open type girders, Double-T pre-stressed girders, Highway bridge crossing railway, experimental study, removable internal shutter.

\section{INTRODUCTION}

A highway bridge across railways in-lieu of the level crossing will surely be smoothening the road traffic and the rail traffic. Adoption of ordinary type girders like I girders, box girders, and steel-concrete composite girders are causing

Revised Manuscript Received on December 25, 2020.

* Correspondence Author

Geetha M. P.*, Ph D Scholar, College of Engineering Trivandrum, India. mpgeetha64@gmail.com

Dr. Girija K., Professor, College of Engineering Trivandrum, India. girijak@cet.ac.in

(C) The Authors. Published by Blue Eyes Intelligence Engineering and Sciences Publication (BEIESP). This is an open access article under the CC BY-NC-ND license (http://creativecommons.org/licenses/by-nc-nd/4.0/) long approach lengths since need to negotiate the total height including the required vertical clearance below the bridge as per the approved schedule of dimensions of railways and the construction depth of bridge superstructure. To maintain the approaches of the bridge as intact, sometimes the need to adopt Double-T cross-section girders arises. An experimental study on two such Double-T cross-section model girders and deck assembly revealed the structural behaviour between girders. Critical aspects in the design methodology could be resolved suitably in comparison with the results of the experiment and elaborated the same in the following sections. Further, the critical aspects in construction like the design of removable internal shutter- an issue in the construction of shallow open type girder with ends closed, the launching scheme, and the demolition and reuse of the girders in case of increase of span, is also brought out in this paper.

\section{MAXIMUM LIVE LOAD CONTRIBUTION TO ONE GIRDER.}

The top dimension of the Double-T cross-section girder has been selected as $1.7 \mathrm{~m}$ to make various deck widths of $6.875 \mathrm{~m}$, $8.6 \mathrm{~m}, 10.325 \mathrm{~m}$, and $12.05 \mathrm{~m}$ with $4,5,6$ and 7 numbers of girders placing apart at a distance of $25 \mathrm{~mm}$. The webs of Double-T girders are at a distance of $980 \mathrm{~mm}$. The general arrangement of girders and enlarged cross-section are as given in figure 1 below.
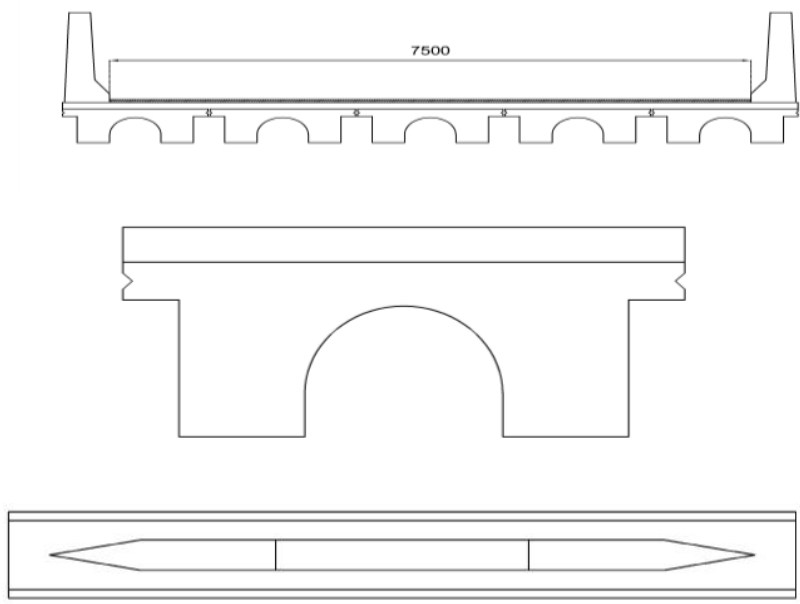

Fig. 1.General arrangement of 5 Girder assembly, Enlarged view of typical cross-section and bottom veiw of one girder

\section{Published By:}


The dimensions of the cross-section of the model girder of effective span $3.8 \mathrm{~m}$ are as tabulated in Table I below against the dimensions of prototype girder of $15 \mathrm{~m}$ span. The dimensions of model girders were suitable to conduct experiment in the laboratory atmosphere.

Table- I:. Dimensions of Model girder and Prototype girder.

\begin{tabular}{|l|l|l|l|}
\hline $\begin{array}{l}\text { Sl. } \\
\text { no. }\end{array}$ & \multicolumn{2}{|c|}{ Prototype girder- span 15000mm } & \multicolumn{1}{|c|}{$\begin{array}{c}\text { Model Girder- } \\
\text { Span 3800mm }\end{array}$} \\
\hline 1 & Top width & $1700 \mathrm{~mm}$ & $910 \mathrm{~mm}$ \\
\hline 2 & Web thickness of & $380 \mathrm{~mm}$ & $160 \mathrm{~mm}$ \\
\hline 3 & $\begin{array}{l}\text { Diameter } \\
\text { semicircle }\end{array}$ & $250 \mathrm{~mm}$ \\
\hline 4 & $\begin{array}{l}\text { a'Straight depth } \\
\text { below semicircular } \\
\text { arch }\end{array}$ & $\begin{array}{l}\text { Thickness of top } \\
\text { slab }\end{array}$ & $1200 \mathrm{~mm}$ \\
\hline 6 & $\begin{array}{l}\text { b Thickness of } \\
\text { cantilever slab }\end{array}$ & $130 \mathrm{~mm}$ & $130 \mathrm{~mm}$ \\
\hline 7 & $\begin{array}{l}\text { Cantilever } \\
\text { projection }\end{array}$ & $\begin{array}{l}\text { Depth of girder } \\
\text { including slab }\end{array}$ & $720 \mathrm{~mm}$ \\
\hline 8
\end{tabular}

a. The straight depth provided for model girder was more to get maximum spread during loading.

b. The thickness of cantilever of girder and that of top slab are the same for both prototype girder and model girder.

The maximum load share to single model girder obtained from grillage analysis and its comparison with the experimental results for the same loading condition of two point loading are as in Table II below;

Table- II:. Comparison of theoretical and experimental results on percentage sharing of load

\begin{tabular}{|c|c|c|c|c|c|}
\hline $\begin{array}{c}\text { Girder. } \\
\text { no. }\end{array}$ & \multicolumn{2}{|c|}{$\begin{array}{l}\text { Result from Grillage } \\
\text { Analysis ( Total load } \\
\text { of } 487.39 \mathrm{kN} \text {, applied } \\
\text { at an eccentricity of } \\
227.5 \mathrm{~mm} \text { to the two } \\
\text { girder deck assembly } \\
\text { (Model)). }\end{array}$} & \multicolumn{3}{|c|}{$\begin{array}{l}\text { Result from Experiment on } \\
\text { model girders, two girders and } \\
\text { deck assembly - on same loading } \\
\text { condition of two point loading. }\end{array}$} \\
\hline $\begin{array}{l}\text { G1 } \\
\text { (loaded) }\end{array}$ & $\begin{array}{l}\mathrm{R} 1+\mathrm{R} 2= \\
368.8 \mathrm{kN}\end{array}$ & $\begin{array}{l}\text { Share to } \\
\text { G1= } \\
75.67 \%\end{array}$ & $\begin{array}{l}\text { Average } \\
\text { Deflection }\end{array}$ & 7.048 & $\begin{array}{l}\text { Share to } \\
\text { G1= } \\
80.4 \%\end{array}$ \\
\hline G2 & $\begin{array}{l}\mathrm{R} 1+\mathrm{R} 2= \\
118.59 \mathrm{kN}\end{array}$ & $\begin{array}{l}\text { Share to } \\
\text { G2 = } \\
24.33 \%\end{array}$ & $\begin{array}{l}\text { Average } \\
\text { Deflection }\end{array}$ & 1.723 & $\begin{array}{l}\text { Share to } \\
\mathrm{G} 2= \\
19.6 \%\end{array}$ \\
\hline
\end{tabular}

The ratio between experimental result and the theoretical result of load share to G1 is 1.063, rounded to 1.07 .

Hence $7 \%$ escalation is suggested to the maximum load share obtained from grillage analysis.

The results from grillage analysis done for the critical lateral load position for the moving load conforming to IRC 6 2014 [1] on 15m span deck of 5 girder assembly are in Table III. Among the two standards of loading conditions, 70R wheeled loading- single lane and IRC class A double lanes, $70 \mathrm{R}$ wheeled loading is the critical loading adopted for the design.

Table- III:. Load share on each girder corresponding to the absolute maximum bending moment due to $70 \mathrm{R}$ wheeled loading.

\begin{tabular}{|c|c|c|c|c|c|}
\hline GIRDERS & $\begin{array}{c}\text { MAX } \\
\text { BM } \\
\text { (kNm) } \\
\end{array}$ & RA (kN) & $\mathrm{RB}(\mathrm{kN})$ & $\begin{array}{c}\mathrm{RA}+\mathrm{RB} \\
(\mathrm{kN})\end{array}$ & $\%$ \\
\hline G1 & -522.76 & 100.401 & 102.427 & 202.828 & $\begin{array}{l}22.0465 \\
2\end{array}$ \\
\hline G2 & -529.74 & 154.797 & 159.542 & 314.339 & $\begin{array}{l}34.1672 \\
8\end{array}$ \\
\hline
\end{tabular}

\begin{tabular}{|l|l|l|l|l|l|} 
& & & & & \\
G3 & -477.99 & 129.167 & 132.758 & 261.925 & 1 \\
\hline G4 & -367.92 & 88.063 & 89.756 & 177.819 & \begin{tabular}{l}
19.3281 \\
\hline G5
\end{tabular} \\
\hline & -284.98 & -18.308 & -18.603 & -36.911 & - \\
\hline
\end{tabular}

The escalated share of the load on G2 $=1.07 * 34.2=36.6 \%$ of total vehicle load on deck.

The position of the first set of the wheel of a vehicle on the deck, conforming to IRC 6-2014 [1], is at a clear distance of $1.2 \mathrm{~m}$ from the crash barrier. Accordingly, the distance to the centerline of the first wheel set is $2.18 \mathrm{~m}$. The centerline of the second girder, with top width $1.7 \mathrm{~m}$ for each one and a gap of $25 \mathrm{~mm}$, from one edge of the bridge deck is $2.575 \mathrm{~m}$.

The eccentricity with respect to the centerline of second girder $=2.575-2.18=0.395 \mathrm{~m}$.

When the load is applied at an eccentricity of $0.395 \mathrm{~m}$ with respect to the centerline of the girder, the effect of the same on open type girder can be accessed like this;

The dispersion of load perpendicular to the span direction through RCC slab and wearing coat to one side is twice the effective depth, including wearing coat thickness, as per IRC 112-2011 [2].

The dispersed width of load $=860+$ $4 *(0.087+0.12+0.125)=2188 \mathrm{~mm}$, eccentric by $395 \mathrm{~mm}$ with respect to the center line of second girder. The portion active on one girder is only $1.549 \mathrm{~m}$. Hence the actual eccentricity after dispersion $=1.7 / 2-1.549 / 2=0.0755 \mathrm{~m}$

The maximum load on one web of critically loaded girder $=$ $0.366 \mathrm{~W}(1 / 2+0.0755 / 0.98)=0.211 \mathrm{~W}$, where $\mathrm{W}$ is the total vehicle load and $0.98 \mathrm{~m}$ is the distance between the centre to centre of two webs of the critically loaded girder(G2).

Since both the webs are pre-stressed equally, it is a must to design one unit girder with $2 * 0.211 \mathrm{~W}=0.422 \mathrm{~W}$. Hence the total escalation required to the result of grillage analysis for achieving the design forces is $0.422 / 0.342=1.234(23.4 \%)$.

Contributions from all other loads like dead-load, superimposed load and impact factor are in the design as usual.

In the calculation, the difference in the load sharing between the webs of the individual girder is as 0.366- $0.211=$ 0.155 . That is, both webs deflections should be in the ratio $0.211 / 0.155=1.36$ times. In the experiment, from two-point load testing on two individual girders in the eccentric position of load, this ratio is observed as in Table IV.

Published By:

Blue Eyes Intelligence Engineering and Sciences Publication

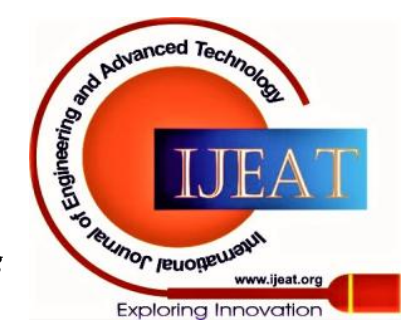


Table- IV:. Ratio between web1 deflection to web2 deflection from experiment results

\begin{tabular}{|c|c|c|c|c|c|c|c|}
\hline \multicolumn{4}{|c|}{ Girder G1 } & \multicolumn{4}{|c|}{ Girder G2 } \\
\hline $\begin{array}{c}\text { Load in } \\
\text { random } \\
\text { range in } \\
\mathbf{k N} \\
\end{array}$ & Deflection in $\mathrm{mm}$ of web 1 & $\begin{array}{c}\text { Deflection } \\
\text { in } \mathrm{mm} \text { of } \\
\text { Web2 }\end{array}$ & $\begin{array}{c}\text { Web1 } \\
\text { deflection/ } \\
\text { Web2 } \\
\text { deflection } \\
\end{array}$ & $\begin{array}{c}\text { Load in } \\
\text { random } \\
\text { range in } \\
\mathrm{kN} \\
\end{array}$ & $\begin{array}{c}\text { Deflection } \\
\text { in } \mathbf{m m} \text { of } \\
\text { web } 1\end{array}$ & $\begin{array}{c}\text { Deflection } \\
\text { in mm of } \\
\text { Web2 }\end{array}$ & $\begin{array}{c}\text { Web1 } \\
\text { deflection/ } \\
\text { Web2 } \\
\text { deflection } \\
\end{array}$ \\
\hline 208 & 3.768 & 4.608 & 1.22 & 541.5 & 12.952 & 10.7 & 1.21 \\
\hline 223.1 & 3.945 & 4.815 & 1.22 & 567.5 & 13.815 & 11.5 & 1.2 \\
\hline 260.8 & 4.395 & 5.335 & 1.21 & 587 & 14.828 & 12.7 & 1.17 \\
\hline 290.7 & 4.738 & 5.738 & 1.21 & 598.5 & 15.74 & 13.7 & 1.15 \\
\hline 304 & 4.922 & 5.972 & 1.21 & 603.1 & 15.938 & 13.9 & 1.15 \\
\hline 334.2 & 5.251 & 6.301 & 1.2 & 618.3 & 17.195 & 15.3 & 1.12 \\
\hline 359.5 & 5.615 & 6.725 & 1.2 & 632 & 18.369 & 16.6 & 1.11 \\
\hline 375 & 5.957 & 7.067 & 1.19 & 639.8 & 19.346 & 17.7 & 1.09 \\
\hline 377.3 & 5.981 & 7.091 & 1.19 & & & & \\
\hline 398.4 & 6.323 & 7.473 & 1.18 & & & & \\
\hline 400.9 & 6.512 & 7.652 & 1.18 & & & & \\
\hline
\end{tabular}

From the above table, it is clear that a reduced percentage of escalation of $21 \%$ against previously arrived value for escalation of $36 \%$, is possible. Reducing $0.211 \mathrm{~W}$, the maximum load share to one web can arrive as $0.2 \mathrm{~W}$ and the other as $0.165 \mathrm{~W}$, to obtain total as $0.366 \mathrm{~W}$, by trial and error method. For the equalized web design, the total load to one girder can arrive as $2 * 0.2=0.4 \mathrm{~W}$. The design load to individual girder deck assembly is then $0.4 \mathrm{~W}$. The corresponding escalation in the total force per girder is $17 \%$ $(0.4 / 0.342=1.17)$ against the previously arrived value of 23.4\%. During the proof load test, the multiple girder assembly should be load tested against higher load so that one girder should get the actual share of total load (here the load share required to one girder is $0.366 \mathrm{~W}$ ) as per IRC SP 51[3].

\section{SHEAR FRICTION REINFORCEMENT}

Provision of shear friction reinforcement is a must to ensure the integration between each girder units. When the vehicle load is above one girder and the other girder is without the same, there is a chance of longitudinal crack on the deck [4]. In the conclusion of this paper, transverse post-tensioning was the solution suggested to this defect. The transverse pre-stressing is not possible to do at the site of bridge constructing above railway tracks. Hence, the authors investigated analytically on the effect of shear friction and found it is feasible to adapt the new detailing with $\mathrm{N}$-type and reversed N-type. [5].Tthe design of N-type and reversed $\mathrm{N}$-Type arrangement of shear friction reinforcement is as below; The nominal shear resistance Vsn is calculated using the formula below;

$$
\mathrm{V}_{\mathrm{sn}} / \mathrm{A}_{\mathrm{cv}}=\mathrm{C} / \mathrm{A}_{\mathrm{cv}}+\mathrm{A}_{\mathrm{vf}} \cdot \mathrm{f}_{\mathrm{y}}(\cos \alpha+\mu \cdot \sin \alpha) / \mathrm{A}_{\mathrm{cv}}{ }^{---} \text {(1) [6] }
$$

Where $A_{c v}$ is the cross-sectional area of concrete resisting the shear, $A_{v f}$ is the area of shear friction reinforcement,

$f_{y}$ is the yield strength of steel, $\mu$ is coefficient of friction and $\alpha$ is the angle of inclination of dowel rods (shear friction reinforcement) based on the vertical plane upon which the shear friction got activated.

The maximum vehicle load affecting the local effect of the longitudinal crack is $103.21 \mathrm{kN}$ (half of the wheel load of $85 \mathrm{kN}$ (maximum) multiplied with the impact factor 1.214286 corresponding to the span $15 \mathrm{~m}$ ) on the span. The required $A_{\mathrm{vf}}$ calculated is $54 \mathrm{~mm}^{2}$. The various inputs for this calculation are mainly the dispersed width of slab, the capacity of shear key alone, the c (or $\mathrm{C} / \mathrm{A}_{\mathrm{cv}}$ ) value, $\mu$ value and $\alpha$ - the angle of dowel bars based on the vertical plane. The contact width of tyre to produce $0.5273 \mathrm{MPa}$ corresponding to the other direction dimension $860 \mathrm{~mm}$ is $187.44 \mathrm{~mm}$. Corresponding dispersed width is $601.44 \mathrm{~mm}$ assuming 45 degrees through wearing-coat and the overall depth of the slab. The capacity of the shear key is $50 \%$ as evaluated from the experimental results. For this, the authors compared the data of the eccentric-load test on two girder-deck assemblies and that of load test done after cutting the integrating deck slab alone. The value of $\mathrm{c}$ and $\mu$ is $1 \mathrm{MPa}$ and 1.4 respectively as per the Canadian Standard, CSA. The value of $\alpha$ is 45 degrees. The provided steel is $8 \mathrm{~mm}$ diameter tor at 280 centre to centre, $A_{v f}=179 \mathrm{~mm}$, in the shape of $\mathrm{N}$ Truss, in fabricated form. Since the vehicle movement is not defined, it is needed to place the reversed $\mathrm{N}$-type steel in the alternative position. Hence, the total shear friction reinforcement of $8 \mathrm{~mm}$ diameter in the form of fabricated steel in the shape of N-type and reversed $\mathrm{N}$-type are to be placed alternatively at a spacing of $140 \mathrm{~mm}$ centre to centre.

\section{MANAGING SPREAD WITH COUNTERACTING PRE-STRESSING FORCE}

The open type girder is tending to spread the webs during the application of load to it. It is approximately $(1 / 10)$ of the radial pressure generated from the curved tendons. The radial pressure due to the curvature of tendons in the plan, calculated for $15 \mathrm{~m}$ girder, is $10.5 \mathrm{kN} / \mathrm{m}$ whereas the thrust generated across the webs when applied with equivalent pressure of vehicle loading, is $1.088 \mathrm{kN}$, analyzed using the software Staad Pro V8i.

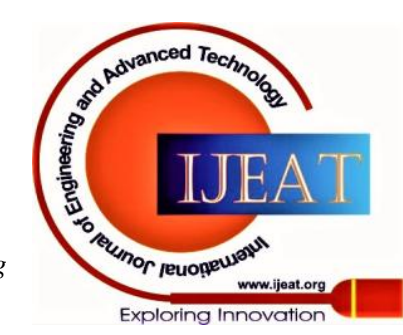


The counteracting force is approximately 10 times the actual thrust generated. The maximum thrust generated for the span of $45 \mathrm{~m}$ is only $1.26 \mathrm{kN}$. Hence, the metallic diaphragms as provided in the case of pi-girders [7] are not at all required for the double $\mathrm{T}$ girders here.

\section{CONCEPTUAL DESIGN OF REMOVABLE INTERNAL BOTTOM SHUTTER FOR OPEN TYPE SHALLOW GIRDER WITH ENDS CLOSED.}

It is a must to remove the internal bottom shutter of the open type shallow girder, with both ends closed, before the pre-stressing. De-shuttering time for cubes of trail mix is the basis for deciding the de-shuttering time of the twin-T girder. The removal of the internal shutter is a difficult task since the girder ends are closed. The reuse of the shutter will reduce the entire construction cost. Hence, the design and modusoperandi of the shutter need to be simple as well as economical. The removal of the internal shutter requires a minimum vertical clearance (VC) of the height of the internal shutter. Hence, the minimum VC required is $600 \mathrm{~mm}$ to $800 \mathrm{~mm}$ from the leveled and firm ground level depending upon the span of the bridge. The straight portion of $5 \mathrm{~m}$, which is standardized for any span girder, will be removed first.

The internal shutter has a $600 \mathrm{~mm}$ diameter at the outside. The plate used to make the $5000 \mathrm{~mm}$ long shutter in semicircle shape will be supported over semicircle ribs at $1.25 \mathrm{~m}$ apart so that the plate thickness can be uniform. The thickness of concrete varies from $450 \mathrm{~mm}$ to $150 \mathrm{~mm}$. A thickness of $0.5 \mathrm{~mm}$ for the steel plate is sufficient to support the concrete continuously through $150 \mathrm{~mm}$ span, the one-third of a quarter of $600 \mathrm{~mm}$ diameter circle. The secondary support to the concrete is the longitudinal bar spanned across the ribs continuously at $1.25 \mathrm{~m}$ span. $12 \mathrm{~mm}$ diameter mild steel rods are sufficient to support the plates above it and to act as runners. The plates will be hooked to these longitudinal rods/runners, as in the case of tiled roof. The semicircular ribs made with $12 \mathrm{~mm}$ diameter mild-steel rods will be the primary supports to the longitudinal rods. Small bits of $12 \mathrm{~mm}$ rods in the horizontal direction will be projecting from the semicircular ribs at a distance of $1 / 3$ rd of the quarter perimeter of $600 \mathrm{~mm}$ diameter. The longitudinal rods will be freely seated over these projections. Figure 2 below shows the framework of these ribs.

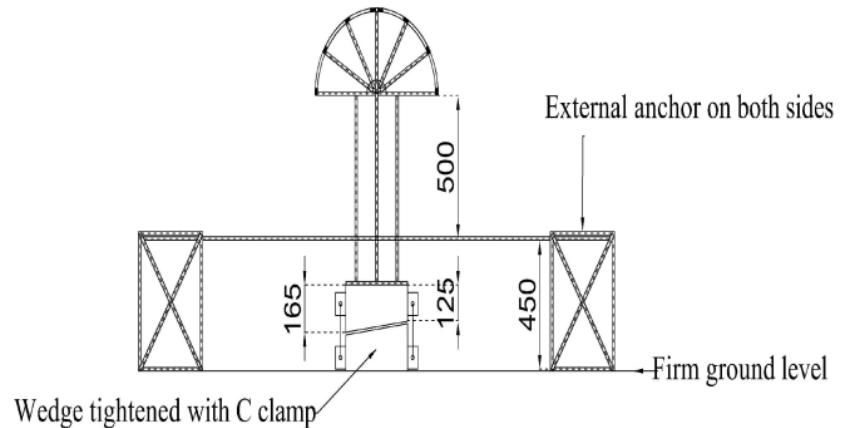

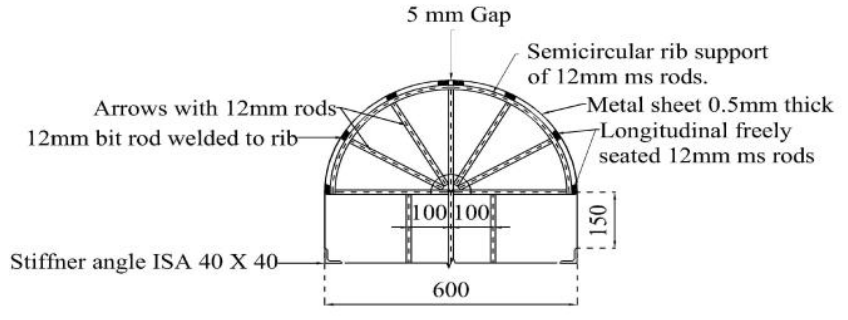

Fig. 2.The arrangement of curved sheet hooked to frame work supported on wedges.

Each rib should be stabilized longitudinally by bracing it to external removable anchors as depicted in figure 3.

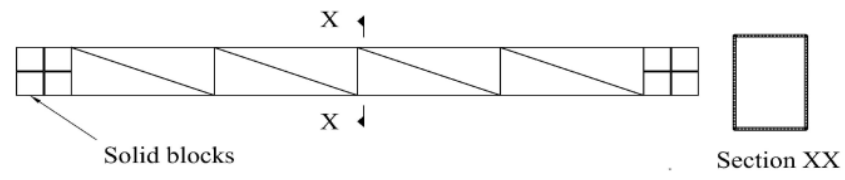

Fig. 3.The arrangement of external anchorages and its enlarged cross-section

\section{MODUS OPERANDI OF SHUTTER REMOVAL}

It is necessary to remove the interior shutters before the pre-stressing to avoid the restraining to the applied pre-stressing force. The procedure of internal shutter removal after de-shuttering time, within 24 hours, is in the sequential order as below.

- Remove the side anchorages.

- Pull the wedges out after removing C clamps.

- Lower the rib frames at every $1.25 \mathrm{~m}$ until blocking over stiffener angles.

- Turn all rib frames after rolling down the freely seated longitudinal rods, with the help of external rods, if required.

- Pull again the shutter segments(made of $0.5 \mathrm{~mm}$ plate and light weight) with external bars until the shutter is detached fully, without damaging the formwork below the webs of girders.

- Pull both end shutters towards the center portion where the shutter was already removed.

\section{CONCEPTUAL LAUNCHING SCHEME OF DOUBLE-T GIRDER}

Each span will be having a minimum of 5 numbers of Double-T girders according to the approved width of the deck. The launching of girders needs to be done in a safe, simple, and economical manner without unnecessary delays. The most complicated part of launching is that of crossing span across railways. The concept of launching the scheme at the site is in the sequential order given below;

1) The casting yard will be suitably at the side of the merging end of one of the approaches and will be parallel to the road.

2) When the substructure is nearing completion, the launching arrangements also can be started.

\section{Published By:}

Blue Eyes Intelligence Engineering

and Sciences Publication 
3) On both sides of the proposed bridge, double rails are to be laid for the movement of Portal frames on four wheels at each side.

4) There will be hanging hoists of required capacity, on portals to pick \& place the PSC girders in position.

5) The clear space at one side of the portal must be around $2 \mathrm{~m}$ to pick each girder from the ground parallel to the axis of the bridge.

6) Two sets of portals should travel at a spacing equal to the span of the girders.

7) The launching girder with nose arrangement and a counterweight at the rear end can be launched first across the railway span with the help of portals, hoists, and winches.

8) The other approach also will be having portals of required and designed capacity.

9) All the girders of crossing span except the last one, will be launched first with the help of launching girder and

10) The last girder will be lifted with the help of hoists at either end. Then, the launching girder plus nose will be pulled back longitudinally with the use of winches and

11) In the same manner, all the Double-T girders will be launched with the help of portals on wheels and hoists on the frame.

12) The girders for the other side need to be launched from the other end.

13) After fitting all the required reinforcements, the deck will be cast for each span separately.

14) All the required accessories like crash barrier, high containment parapets, etc will be cast on the next day of the casting of the deck slab.

15) The road will be commissioned after proper curing and

\section{DISMANTLING OF BRIDGE AND ITS SUSTAINABILITY}

The increased span of the bridge is required when the number of tracks increases during any development program of railways. At that time, it is easy to demolish the bridge by just cutting the thin deck slab above the joint with a concrete cutter and then drilling holes as close as possible using a jackhammer. Screw Jacks can be placed horizontally at ends in the gap between girders to separate girders. Reusing of these girders is possible at any suitable location after joining the slab by breaking at certain intervals and placing the shear friction reinforcements.

\section{CONCLUSION}

A design methodology focused on critical aspects in the design of Double-T girders, a most suitable cross-section of shallow open type girders to bridge above busy railway tracks, with closed ends, could be evolved in this study. The following are the findings evolved;

1. An escalation of $17 \%$ in the design forces need to be considered on the results obtaining from the grillage analysis, to cater the unbalanced forces on the individual web of the open-type girder, during the eccentric loading condition. hoist arrangement. counter weight arrangement and will be removed back. further finishing works.

2. The Authors elaborated the design of shear friction reinforcement.

3. The self-managing capacity of the spreading tendency of the webs of shallow open-type girders is due to the counteracting of radial pressure generated from the pre-stressing force. In addition to this, the authors presented conceptual designs for removable interior shutters that are economical and safe, a suitable launching scheme and the dismantling of the bridge for want of rehabilitation with increased span including reuse of girders. With the implementation of these conceptual designs only, the construction of open-type shallow girders can be encouraged. By using shallow open-type, pre-stressed girders and integrating deck assembly in highway bridge superstructure construction, the conversion of level crossings will become accelerated in many developing countries.

\section{ACKNOWLEDGEMENT}

This research was a pilot experimental study to the study on prototype girder-deck assembly corresponding to the $15 \mathrm{~m}$ effective-span, funded by Technology Development and Transfer, Department of Science and Technology, India.

\section{REFERENCES}

1. IRC:6 (2014). "Standard specifications and code of practice for road bridges.” INDIAN ROAD CONGRESS, New Delhi

2. IRC:112 (2011). "Code of practice for concrete road bridges." INDIAN ROAD CONGRESS, New Delhi.

3. IRC:SP 51 "Guidelines for load Testing of Bridges" INDIAN ROAD CONGRESS, New Delhi.

4. C. C. Fu, Z. Pan and M. S. Ahamed, "Transverse post tensioned design of adjacent precast solid multibeam Bridges," ASCE, Journal of performance of constructed facilities, vol. 25, no. 3, June 2011.

5. Geetha. M. P. and Girija. K. , "Analytical Investigation on Effect of Shear Friction,A critical Issue in Accelerated Construction of Bridge Superstructures," in 3rd International Conference- IMMM, 2017.

6. S Unnikrishna Pillai and Devdas Menon, Reinforced Concrete Design, 3rd ed., McGraw Hill Education(India) Private Limited, 2009, pp. 254 258.

7. L. Chen and B. A. Graybeal, "Modelling Structural Performance of Second-Generation Ultrahigh-preformance Concrete Pi-Girders," ASCE, Journal of Bridge Engineering, vol. 17, no. 4, 27 July 2012.

\section{AUTHORS PROFILE}

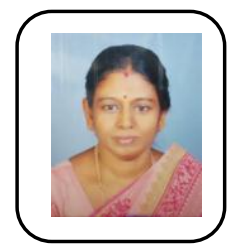

Geetha M. P is currently a Research Scholar in Structural Engineering. She completed her M.Tech. from College of Engineering Trivandrum. She worked as Assistant Executive Engineer in Southern Railways and in Kerala Rail Development Corporation. Her interested field is Design and Construction of various types of bridges.

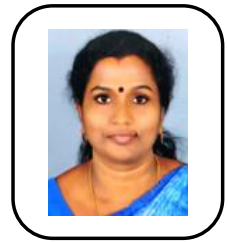

Dr. Girija K. did her Masters in Structura Engineering from T.K.M. college of engineering, Kollam, kerala and her Ph.D in Structural Engineering from IIT Madras. Her areas of interest include Reinforced Concrete Structures, Pre-stressed Concrete, Stability of Structures and Earthquake Engineering. She has been Member of Senate, University of Kerala (2014-18). She worked as Assistant Engineer in Harbor Engineering Department and Public Work Department. Currently She is Professor in the department of Civil Engineering of College of Engineering Trivandrum.

\section{Published By:}

Blue Eyes Intelligence Engineering and Sciences Publication

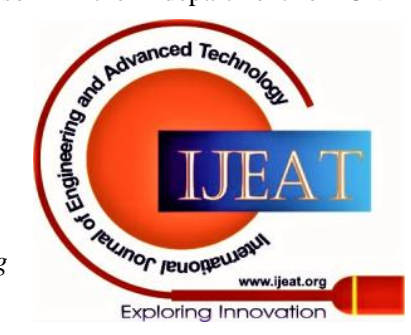

